\title{
A Study on the Outbound Tourism Preferences of China, Japan and South Korea for ASEAN Countries and Its Causes*
}

\author{
Wen Pang \\ School of Tourism \& Research Institute of Human \\ Geography \\ Xi'an International Studies University \\ Xi'an, China
}

\author{
Siyi Zhu \\ School of Tourism \& Research Institute of Human \\ Geography \\ Xi'an International Studies University \\ Xi'an, China
}

\begin{abstract}
This article analyzes the number of tourists from China, Japan and South Korea to ASEAN countries from 1997 to 2016 and the import and export volume of tourism service trade of ASEAN countries from 2005 to 2016 from three perspectives: tourist flow, tourism preferences and tourism competitiveness. It's found in the study that China, Japan and South Korea have different outbound tourism preferences for ASEAN countries and have different trends. In the study of tourism competitiveness, the three indicators of export market share, trade advantage index, and explicit comparative advantage are used to analyze ASEAN countries, and it is found that the travel preferences of China, Japan and South Korea for ASEAN countries are positively correlated to their tourism competitiveness.
\end{abstract}

Keywords-China, Japan and South Korea; ASEAN; outbound tourism; tourism preferences; tourism competitiveness

\section{INTRODUCTION}

Inter-regional cross-border tourism is an important area of tourism study. Scholars at home and abroad have done a lot of studies on this area. Early foreign studies mainly discussed the strategy for sustainable development and market competitiveness of regional tourism from the perspective of the market competition in tourist destinations, focusing on market positioning, information, destination image building, sustainable development and competitiveness. American scholar O'Ina, French scholar La Lansow, and Danish scholar Paul Rita have all conducted relevant studies [1]. Ma Yong proposed the marketing strategy of the Asia-Pacific tourism market on the basis of analyzing the development trends and characteristics of the Asia-Pacific tourism market [2]. Zhang Meng completely built a comprehensive evaluation index system for regional tourism on the basis of analyzing the tourist regions in the east and west China [3].

The ASEAN 10+3 Organization is rich in tourism

*Fund Project: Special Research Project of Shaanxi Provincial Department of Education, Study on the Composition, Measurement and Development Model of Social Capital in Tourist Destinations: Taking China's Inbound Tourism as an Example (17JK062). The research fund project of Xi'an International Studies University, "Research on Sustainable Development Index of countries along "Belt and Road"(2018XWD01) resources, which attracts tourists from all over the world with its natural landscapes such as peninsulas and islands, as well as diverse religious and folk cultures. In 2016, the travel persontime to the 10 ASEAN countries rose by nearly 3 times year on year. Among them, Thailand, the Philippines, Vietnam, Singapore and Indonesia were the five most popular destinations for tourists. In 2016, China's outbound tourism market reached 122 million person-times, and outbound tourism expenditures reached 109.8 billion US dollars, indicating huge market potential. At present, domestic and foreign tourism studies on ASEAN mainly focus on tourism competition and tourism trade interaction. In terms of tourism competitiveness, Douglas discussed the construction and implementation of tourism competitiveness in Southeast Asia [4]. Zou Chunmeng discussed the role of ASEAN tourism cooperation in promoting the overall tourism development in the region [5]. Su Kewu used the panel data from 1990 to 2006 to analyze the international competitiveness of China and ASEAN's tourism service trade, and concluded that the competitiveness of China's tourism service trade is inferior to that of the overall tourism service trade of the ten ASEAN countries[6]. Van Narris believes that tourism cooperation in Southeast Asia has become an important part of regional integration, and the cooperation and integration process of regional tourism has created a "spillover effect" for the promotion of ASEAN tourism competitiveness [7]. Ye Li and Chen Xiuqian took the entropy method to comprehensively evaluate the competitiveness of international tourism of China and six ASEAN countries and built an interactive conceptual model of tourism trade [8]. Hu Aiqing proposed the strategy for ASEAN as a whole to enhance regional tourism competitiveness on the basis of analyzing the regional competitiveness of ASEAN[9]. In terms of interactive study of tourism trade, Sun Gennian and Zhou Lu proposed a threestage model of interaction between tourism and trade, in which statistical data from 1998 to 2009 was used to analyze the relationship between tourism of Japan, South Korea and eight ASEAN countries to China and import \& export trades[10]. Chen Qiao conducted an empirical study on the dynamic equilibrium relationship between inbound tourism and import \& export trades, and concluded that inbound tourism contributes more to the growth of export trade than to import 
trade, and in the current relationship between tourism and trade between China and ASEAN, trade drives tourism[11]. Among the above studies, domestic studies mainly focus on the regional tourism competitiveness and tourism trade, most of which take ASEAN as a whole, and there are less studies on ASEAN's inbound tourism preferences that take ASEAN member countries as an object of study, and adopt multiple perspectives and long-term axes. From the three perspectives of tourist flow, outbound travel preferences, and tourism competitiveness, this paper selects three countries: China, Japan, and South Korea, the number of people entering ASEAN 1997 to 2015 and the amount of import \&export of ASEAN countries from 2005 to 2016 , to analyze the preferences of ASEAN member countries and causes.

\section{DATA SOURCES AND RESEARCH METHODS}

\section{A. Data Sources}

The data in this paper is taken from the ASEAN Statistical Yearbook, including the outbound tourist flow of China, Japan and South Korea to ASEAN from 1997 to 2016, and the export service trade of China, Japan and South Korea to ASEAN countries from 2005 to 2016. Data statistics for some years are missing, and median interpolation is used to approximate the value.

\section{B. Research Methods}

- The statistical data for the past 19 years is used, nonlinear correlation analysis is conducted using time series data in different countries, to analyze the changes and development of tourist flows of the three countries in the development of outbound tourism from China, Japan and South Korea to ASEAN countries, reveal their development process and stages, as well as changes in cumulative values, tendency rates, and growth rates, and recognize the general situation of outbound tourism of China, Japan, and South Korea to ASEAN.
- The concept of outbound tourism preferences as defined in the paper is used to analyze the changes in the preferences of China, Japan and South Korea for ASEAN countries in the past 19 years of outbound tourism from China, Japan and South Korea to ASEAN countries.

- Indexes such as export market share index, trade competition advantage index and revealed comparative advantage index are used to analyze the ASEAN countries' competitiveness in tourism service trade.

\section{RESULTS AND ANALYSIS}

\section{A. Statistics and Analysis of Tourist Flows}

1) Total outbound tourists from China, Japan and South Korea to ASEAN: Through the analysis of outbound tourist flows from China, Japan and South Korea to ASEAN from 1997 to 2016, it can be seen that 2006 was an important demarcation point of outbound tourism from China, Japan and South Korea to ASEAN. Before 2006, the three countries remained at a relatively low level; after 2006, the tourist flows of China and South Korea increased, and the tourist flow of China increased rapidly. In 2007, China surpassed Japan for the first time, ranking first and maintaining its advantages to 2016.

The overall outbound tourist flows of Japan and South Korea shows an increasing trend. 2010 is the demarcation line of China's outbound tourist flow. Before 2010, it was steady vibrating growth; after 2010, it was rapid vibrating growth. From 1997 to 2010, China's outbound person-times increased from 1.299 million to 5.416 million, with an average annual increase of 295,000 person-times. From 2010 to 2016, the person-times increased from 5.416 million to 20.339 million, with an average annual increase of 2.132 million person-times, and the average increase in 2010-2016 was 7 times the average increase in 1997-2010.

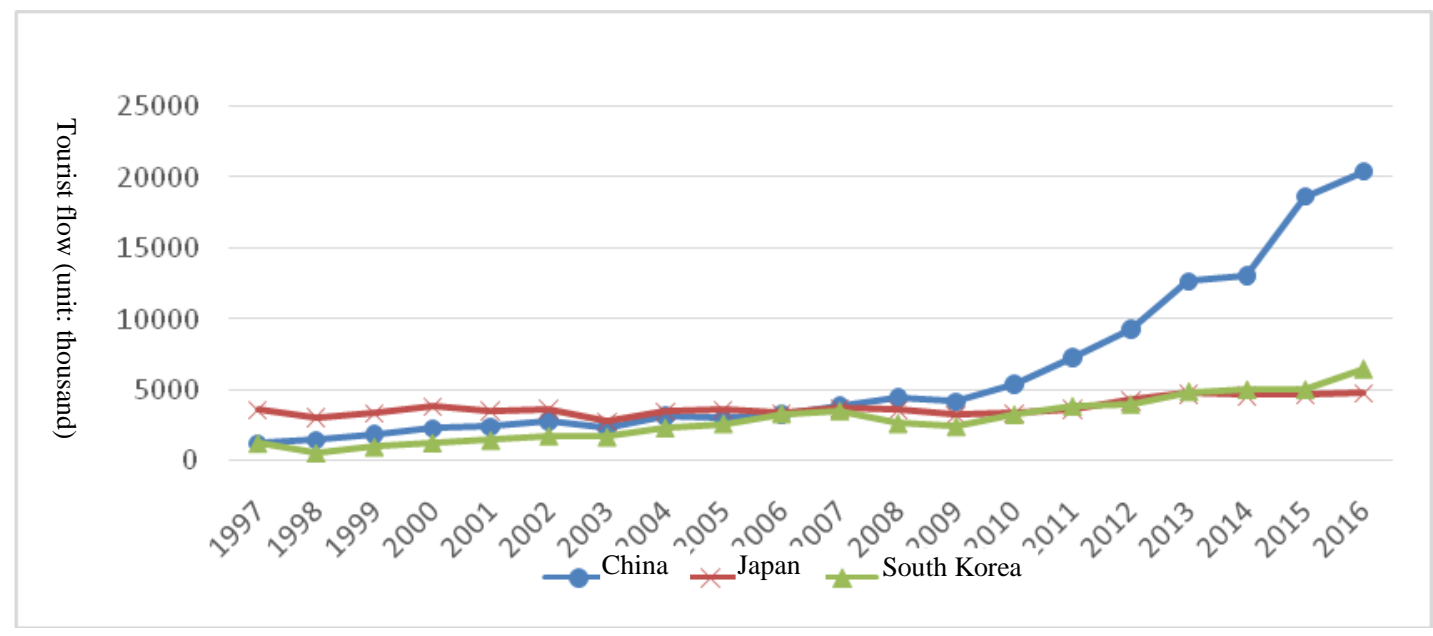

Fig. 1. Total number of outbound tourists from China, Japan and South Korea to ASEAN. 
2) Outbound tourist flows from China to ASEAN Countries: The overall outbound tourist flow from China to ASEAN countries shows a trend of growth. Before 2010, all countries were at a low-speed, steady growth stage, and experienced major changes since 2010. After 2010, they could be classified into four types: (1) Low-speed sustained growth type, including Brunei, the Philippines, Laos, Indonesia, and Cambodia, with slow sustained growth. (2) Medium-speed fluctuating growth type, including Singapore, Vietnam, Malaysia, with rapid growth in fluctuations. (3) High-speed sustained growth type includes Thailand, which had the fastest growth rate with the largest growth amount in 20102015. (4) Non-linear growth type includes Myanmar, which showed slow sustained growth in 2010-2013, and fast sustained growth in $2013-2015$. Tourism is greatly affected by the environment both at home and abroad, and the changes in the number of outbound tourists in China are inseparable from the domestic and foreign environment.

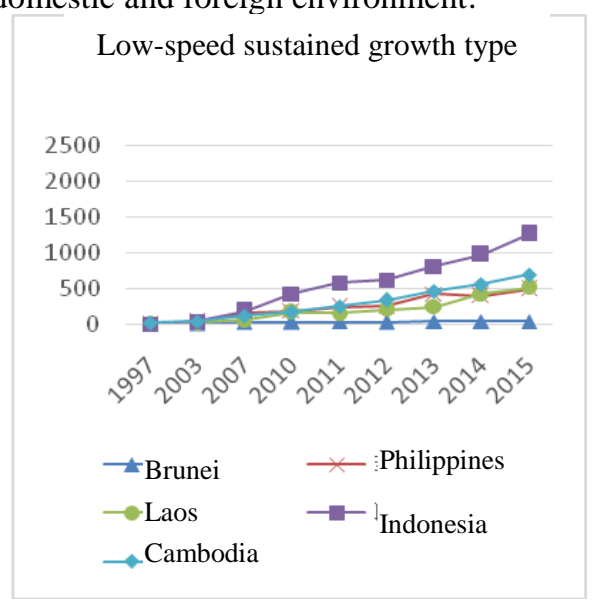

Fig. 2. Low-speed sustained growth type of outbound tourist flows from China to 10 ASEAN countries (Unit: 1,000 people).

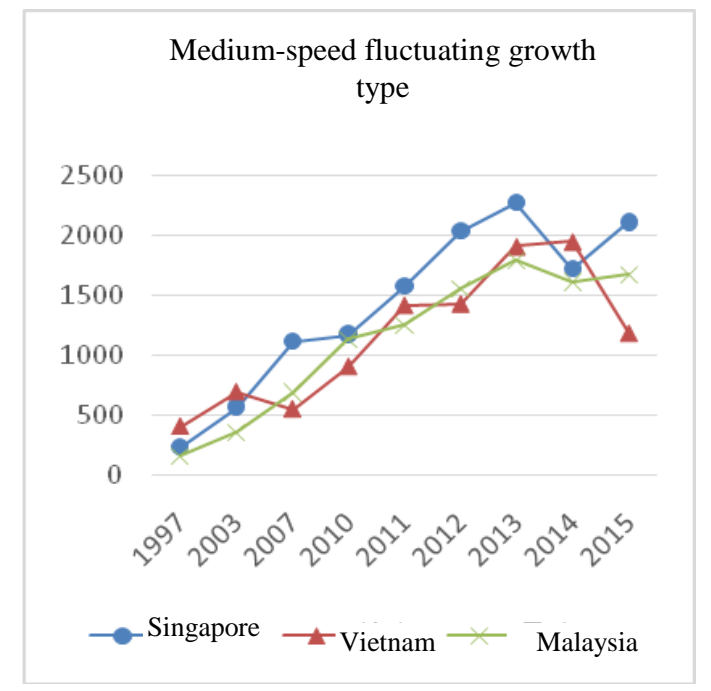

Fig. 3. Medium-speed fluctuating growth type of outbound tourist flows from China to 10 ASEAN countries (Unit: 1,000 people).

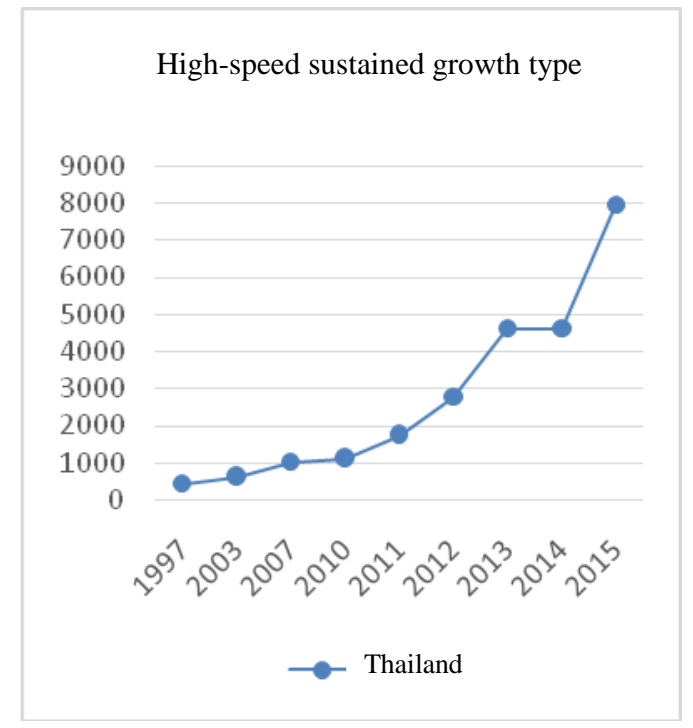

Fig. 4. High-speed sustained growth type of outbound tourist flows from China to 10 ASEAN countries (Unit: 1,000 people).

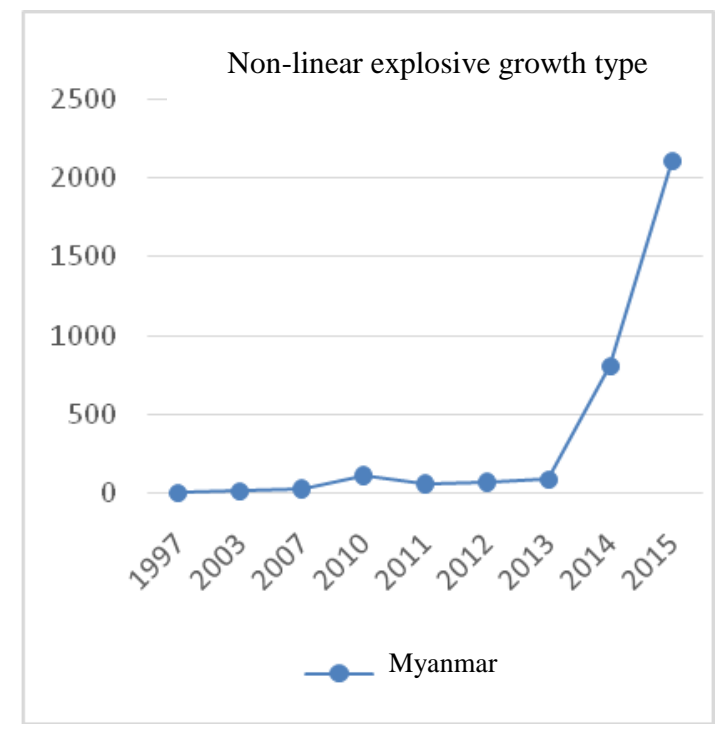

Fig. 5. Non-linear explosive growth type of outbound tourist flows from China to 10 ASEAN countries (Unit: 1,000 people).

3) Outbound tourist flow from Japan to ASEAN countries: The overall outbound tourist flow from Japan to ASEAN countries is on the rise but growth is slow. From 1997 to 2015 , the trend of outbound tourist flow from Japan to ASEAN countries could be classified into three types: (1) Thailand, Malaysia, the Philippines, and Vietnam belonged to the fluctuating growth type. The trend of fluctuations in the four countries was basically the same, but the growth amount was greatly different, among which Thailand increased greater than the three other countries; (2) Singapore and Indonesia belonged to fluctuating decline type, although the two countries had growth, the general trend was declining, which were the only two countries with reduced tourist flow; (3) 


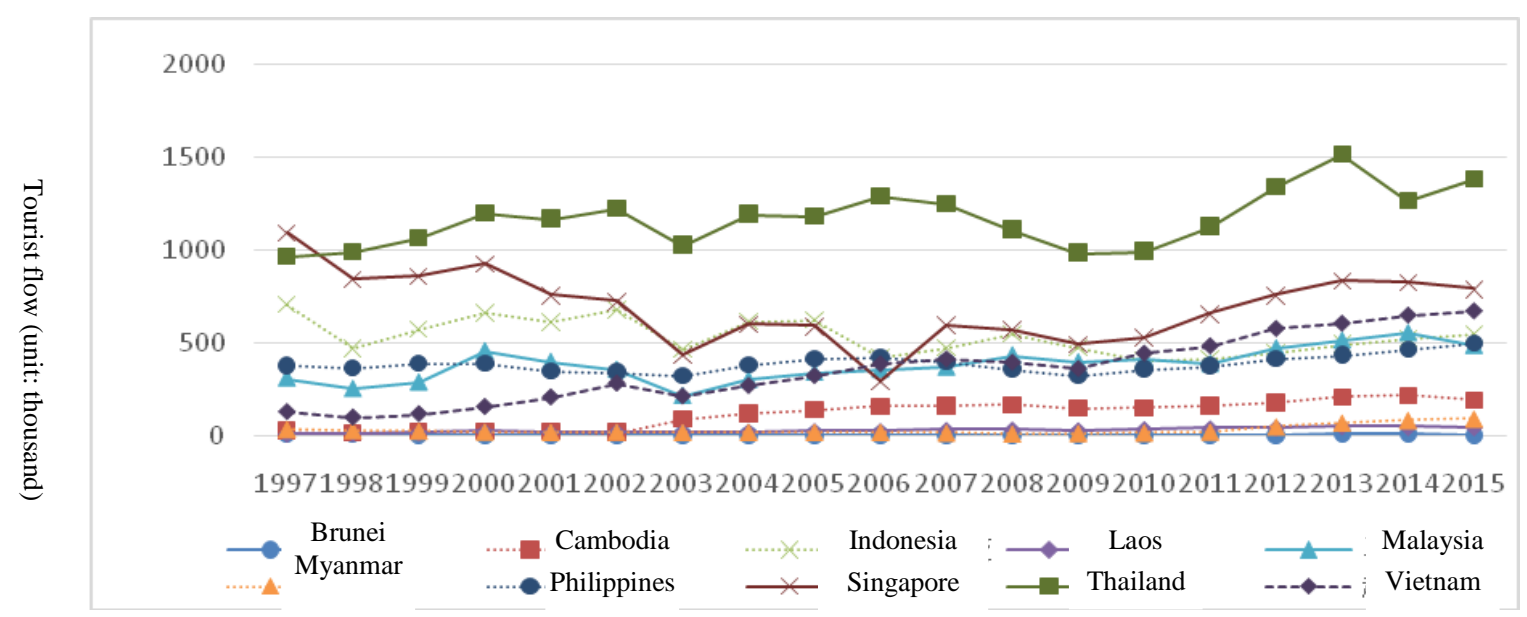

Fig. 6. Japan's outbound tourist flow to 10 ASEAN countries.

4) Outbound tourists from South Korea to ASEAN countries: There has been great fluctuations in the number of outbound tourists from South Korea to ASEAN countries, which is basically divided into four stages: (1) In 1997-1998, affected by the Asian financial crisis, the number of tourists to all ten countries declined; (2) In 1998-2007, it maintained steady growth, during which the number of outbound tourists declined slightly in 2003 due to "SARS crisis"; (3) Affected by the subprime mortgage crisis in the US, in 2007-2009, except for the increase in Laos in 2007-2008, the number of tourists to other countries declined, and Thailand experienced the greatest fluctuation, which fell to the lowest in 2008 and quickly recovered in 2009; (4) The number of tourists to all countries maintained high-speed growth in 2009-2015, among which Cambodia experienced the greatest fluctuation, which fell sharply in 2012, and rapidly grew in 2013 with subsequentn stabilization.

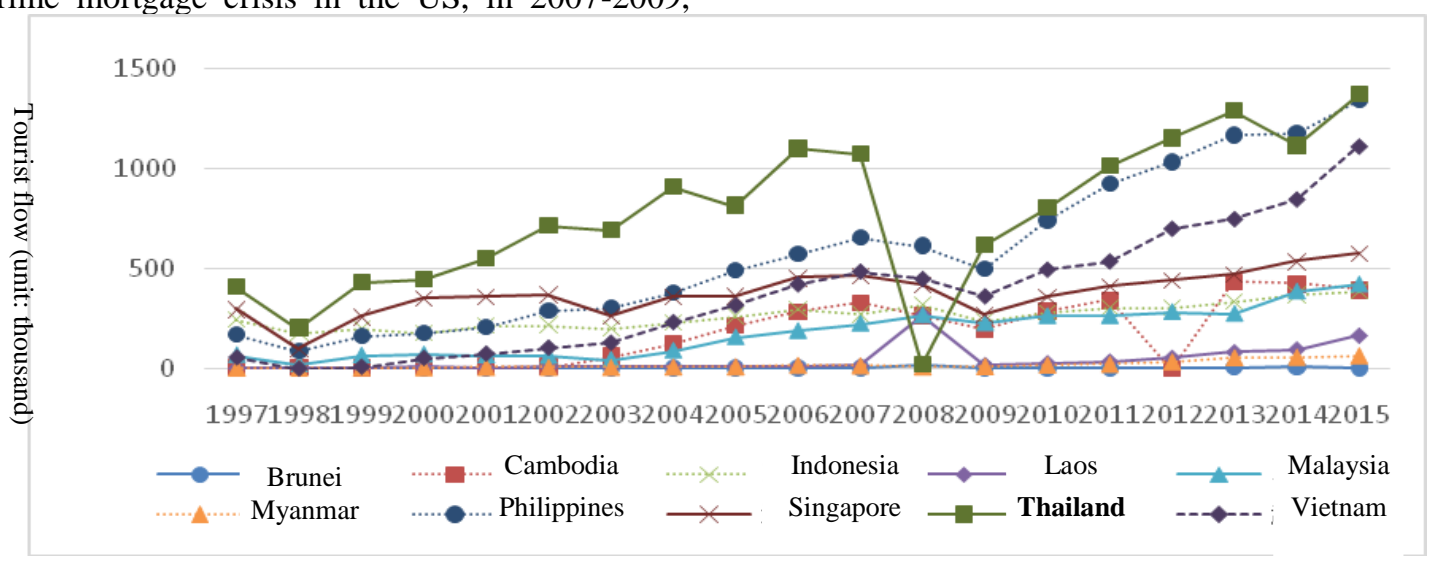

Fig. 7. South Korea's outbound tourist flow to 10 ASEAN countries.

\section{B. Analysis of Outbound Tourism Preferences}

The differences among China, Japan, and South Korea in land area, population size, economic development, etc., have different meanings for ASEAN countries. Based on the analysis of ASEAN tourism, this paper defines outbound tourism preferences as the proportion of outbound travel, namely the proportion of the outbound tourist flow from a country to another country to the total outbound tourist flow from that country to ASEAN that year. China, Japan, and South Korea are all major tourist source countries for ASEAN with close geographical location. However, affected by political environment, economic level, and cultural background, China, Japan and South Korea have different tourism preferences for ASEAN countries. According to "Table I", preference is divided into four levels: high preference $(20 \%-40 \%)$, relatively high preference $(10 \%-20 \%)$, relatively low preference $(10 \%-5 \%)$, low preference $(5 \%$ or less). According to the consistency situation, China, Japan and South Korea's preferences for the 10 countries are divided into four categories: China, Japan and South Korea, China and South Korea, China and Japan, and Japan and South Korea.

- China, Japan and South Korea had the same preference. China, Japan and South Korea had the same preference for Thailand, Singapore, Laos, and 
Myanmar, which can be divided into two categories according to the level of preference: A. High preference: Thailand, Singapore. South Korea's preference for Thailand was $0.83 \%$ in 2008, which was the lowest in history, and it fluctuated between $20 \%-40 \%$ in other years. In the US subprime crisis in 2007, South Korea's economic dependence on foreign exchange was high. Affected by the subprime crisis, the domestic economy declined, and therefore the number of outbound tourists declined. The changes in the preference of the three countries for Singapore were different. Japan and South Korea's preference for Singapore continued to decline, and China's preference for Singapore continued to increase from 1997 and then continued to decline after the peak in 2006. B. Low preference: Laos, Myanmar. The preference for both Laos and Myanmar was low, but it was rising. China, Japan and South Korea's preference for Myanmar all basically fluctuated below 3\%, however, China's preference for Myanmar was 6.19\% in 2014 and $11.31 \%$ in 2015, with a trend toward relatively low preference. South Korea's preference for Laos was below $1 \%$ before 2008 , which increased to $10.5 \%$ in 2008, and then fluctuated below 3\%. In 2008, affected by the economic crisis, South Korea's national income declined, and the number of outbound tourists declined, especially the tourists to Thailand. However, the number of tourists to Laos increased, which was closely related to the low tourism expenditures in Laos.

- China and South Korea had the same preference. China and South Korea have the same preferences for Brunei and Indonesia, which were both low. Both China and South Korea's preferences for Brunei fluctuated below $1 \%$, and South Korea's preference for Indonesia fluctuated below $0.3 \%$, which was extremely low. Before 2007, China's preference fluctuated below $2 \%$, which was low, and it fluctuated between 5\%-9\% after 2007, with preference increased. Indonesia is rich in natural resources and has worldfamous tourist attractions such as Bali. However, due to the incident of Chinese exclusion in 1998, China's preference for Indonesia has always been low. The impact of anti-China events began to subside in 2007, and China's preference for Indonesia began to increase Japan's preference for Brunei and Indonesia was relatively high, that for Brunei fluctuated greatly but the trend of change was stable, and that for Indonesia showed a downward trend in fluctuations.

- China and Japanese have the same preference. China and Japan have a low preference for Cambodia, whichis on the rise. South Korea's preference for Cambodia is relatively low, which also shows an upward trend.

- Japan and South Korea had the same preference. Japan and South Korea had the same preference for the Philippines, Malaysia, and Vietnam. Japan and South Korea had relatively high preference for the Philippines, while Japan experienced steady changes with little fluctuation. South Korea's preference was increasing. Japan and South Korea had relatively low preference for Malaysia and Vietnam, between which their preference for Vietnam was rising rapidly in fluctuations, and their preference trend for Malaysia was steady in fluctuations. China had a relatively low preference for the Philippines, which was relatively stable, and its preference for Vietnam was in a downward trend from high preference to relatively high preference.

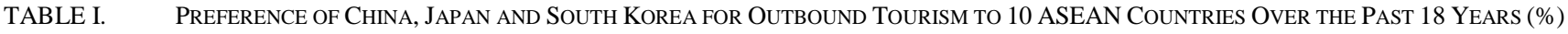

\begin{tabular}{|c|c|c|c|c|c|c|c|c|c|c|}
\hline & & 1997 & 1998 & 1999 & 2000 & 2001 & 2002 & 2003 & 2004 & 2005 \\
\hline \multirow{3}{*}{ Brunei } & China & 0.03 & 0.07 & 0.05 & 0.26 & 0.25 & 0.25 & 0.29 & 0.16 & 0.13 \\
\hline & Japan & 16.43 & 22.8 & 8.97 & 10.37 & 5.65 & 8.19 & 10.73 & 5.68 & 5.48 \\
\hline & South Korea & 0.08 & 0.34 & 0.2 & 0.15 & 0.07 & 0.06 & 0.06 & 0.04 & 0.04 \\
\hline \multirow{3}{*}{ Cambodia } & China & 1.31 & 1.19 & 1.41 & 1.34 & 1.32 & 0.99 & 1.63 & 1.45 & 1.96 \\
\hline & Japan & 0.68 & 0.42 & 0.6 & 0.52 & 0.51 & 0.46 & 3.15 & 3.35 & 3.78 \\
\hline & South Korea & 0.63 & 0.67 & 0.2 & 0.61 & 0.67 & 0.56 & 3.61 & 5.45 & 8.2 \\
\hline \multirow{3}{*}{ Indonesia } & China & 0 & 0 & 0.78 & 1.21 & 0 & 0.7 & 1.71 & 1.6 & 1.76 \\
\hline & \begin{tabular}{|l|} 
Japan \\
\end{tabular} & 19.36 & 15.28 & 17.07 & 17.17 & 17.27 & 18.57 & 16.55 & 17.5 & 17.04 \\
\hline & South Korea & 0.19 & 0.3 & 0.2 & 0.14 & 0.14 & 0.12 & 0.12 & 0.1 & 0.1 \\
\hline \multirow{3}{*}{ Laos } & China & 1.39 & 1.06 & 1.04 & 1.21 & 1.69 & 0.78 & 0.88 & 1.04 & 1.3 \\
\hline & \begin{tabular}{|l|} 
Japan \\
\end{tabular} & 0.25 & 0.42 & 0.45 & 0.54 & 0.45 & 0.55 & 0.64 & 0.57 & 0.63 \\
\hline & South Korea & 0.16 & 0.17 & 0.39 & 0.38 & 0.27 & 0.28 & 0.29 & 0.3 & 0.34 \\
\hline \multirow{3}{*}{ Malaysia } & China & 12.24 & 10.58 & 9.95 & 18.37 & 18.62 & 19.67 & 14.67 & 17.29 & 11.71 \\
\hline & Japan & 8.46 & 8.21 & 8.58 & 11.83 & 11.25 & 9.7 & 7.65 & 8.55 & 9.32 \\
\hline & South Korea & 3.69 & 6.58 & 5.53 & 4.48 & 3.58 & 2.68 & 3.87 & 5.97 & 5.64 \\
\hline \multirow{3}{*}{ Myanmar } & China & 0.46 & 0.53 & 0.63 & 0.61 & 0.7 & 0.63 & 0.67 & 0.57 & 0.67 \\
\hline & \begin{tabular}{|l|} 
Japan \\
\end{tabular} & 0.96 & 0.94 & 0.75 & 0.57 & 0.57 & 0.57 & 0.68 & 0.57 & 0.55 \\
\hline & South Korea & 0.39 & 0.67 & 0.59 & 0.54 & 0.53 & 0.45 & 0.47 & 0.43 & 0.42 \\
\hline \multirow[b]{3}{*}{ Philippines } & China & 1.46 & 1.59 & 1.09 & 0.65 & 0.78 & 0.99 & 1.34 & 1.26 & 3.56 \\
\hline & \begin{tabular}{|l|} 
Japan \\
\end{tabular} & 10.32 & 11.79 & 11.6 & 10.14 & 9.72 & 9.34 & 11.55 & 10.85 & 11.37 \\
\hline & South Korea & 13.42 & 14.77 & 15.72 & 13.43 & 13.9 & 16.11 & 17.72 & 16.13 & 18.49 \\
\hline
\end{tabular}




\begin{tabular}{|c|c|c|c|c|c|c|c|c|c|c|}
\hline & & 1997 & 1998 & 1999 & 2000 & 2001 & 2002 & 2003 & 2004 & 2005 \\
\hline \multirow[b]{3}{*}{ Singapore } & China & 18.09 & 19.38 & 19.43 & 18.76 & 20.43 & 23.62 & 23.74 & 27.66 & 28.53 \\
\hline & Japan & 29.96 & 27.49 & 25.73 & 24.12 & 21.37 & 19.75 & 15.52 & 17.02 & 16.14 \\
\hline & South Korea & 23.52 & 16.61 & 25.54 & 27.17 & 24 & 20.75 & 15.21 & 15.36 & 13.76 \\
\hline \multirow{3}{*}{ Thailand } & China & 33.87 & 37.76 & 40.42 & 30.44 & 28.57 & 26.89 & 26.12 & 24.52 & 25.34 \\
\hline & Japan & 26.42 & 32.12 & 31.83 & 31.07 & 33.04 & 33.38 & 36.68 & 33.92 & 32.38 \\
\hline & South Korea & 32.44 & 34.06 & 42.24 & 34.38 & 36.97 & 40.1 & 40.5 & 38.77 & 30.85 \\
\hline \multirow{3}{*}{ Vietnam } & China & 31.18 & 27.84 & 25.21 & 27.06 & 27.62 & 25.52 & 28.96 & 24.46 & 25.04 \\
\hline & Japan & 3.42 & 3.09 & 3.41 & 3.97 & 5.79 & 7.65 & 7.51 & 7.59 & 8.79 \\
\hline & South Korea & 4.42 & 0 & 0.88 & 4.07 & 5.01 & 5.87 & 7.58 & 9.91 & 11.98 \\
\hline
\end{tabular}

TABLE II. PREFERENCE OF ChInA, JAPAN, SOUth KOREA FOR OUtBound TOURISM to 10 ASEAN COUNTRIES OVER THE PAST 18 YeARS (\%)

\begin{tabular}{|c|c|c|c|c|c|c|c|c|c|c|c|}
\hline & & 2006 & 2007 & 2008 & 2009 & 2010 & 2011 & 2012 & 2013 & 2014 & 2015 \\
\hline \multirow{3}{*}{ Brunei } & China & 0.6 & 0.71 & 0.63 & 0.38 & 0.46 & 0.45 & 0.29 & 0.32 & 0.3 & 0.2 \\
\hline & Japan & 8.91 & 10.81 & 11.04 & 12.45 & 11.94 & 10.92 & 9.36 & 19.05 & 21.58 & 8.51 \\
\hline & South Korea & 0.12 & 0.11 & 0.68 & 0.08 & 0.06 & 0.05 & 0.1 & 0.1 & 0.12 & 0.06 \\
\hline \multirow{3}{*}{ Cambodia } & China & 2.43 & 3.01 & 2.91 & 3.05 & 3.29 & 3.38 & 3.6 & 3.66 & 4.29 & 3.74 \\
\hline & Japan & 4.69 & 4.38 & 4.53 & 4.54 & 4.54 & 4.42 & 4.19 & 4.38 & 4.66 & 4.1 \\
\hline & South Korea & 8.5 & 9.32 & 10.05 & 8.08 & 8.83 & 8.88 & 0 & 8.93 & 8.45 & 7.87 \\
\hline \multirow{3}{*}{ Indonesia } & China & 0 & 4.61 & 7.54 & 8.88 & 7.79 & 7.85 & 6.66 & 6.38 & 7.44 & 6.78 \\
\hline & Japan & 12.44 & 12.81 & 15.09 & 14.62 & 12.12 & 11.27 & 10.41 & 10.41 & 11.33 & 11.69 \\
\hline & South Korea & 0.09 & 0.08 & 0.12 & 0.1 & 0.09 & 0.08 & 0.08 & 0.07 & 0.07 & 0.08 \\
\hline \multirow{3}{*}{ Laos } & China & 1.5 & 1.4 & 2.37 & 3.05 & 2.99 & 2.06 & 2.15 & 1.94 & 3.23 & 2.75 \\
\hline & Japan & 0.68 & 0.81 & 0.88 & 0.87 & 1.01 & 1.04 & 0.98 & 1.04 & 0.97 & 0.94 \\
\hline & South Korea & 0.33 & 0.37 & 10.05 & 0.73 & 0.82 & 0.91 & 1.35 & 1.68 & 1.91 & 3.29 \\
\hline \multirow{3}{*}{ Malaysia } & China & 13.16 & 17.55 & 21.11 & 24.27 & 20.86 & 17.1 & 16.79 & 14.16 & 12.35 & 9.02 \\
\hline & Japan & 10.51 & 9.94 & 11.95 & 12.32 & 12.41 & 10.56 & 10.99 & 10.86 & 11.93 & 10.29 \\
\hline & South Korea & 6.36 & 10.05 & 9.27 & 8.03 & 6.81 & 7.08 & 5.64 & 7.69 & 8.39 & 8.39 \\
\hline \multirow{3}{*}{ Myanmar } & China & 0.75 & 0.76 & 2.19 & 2.43 & 2.1 & 0.85 & 0.76 & 0.72 & 6.19 & 11.31 \\
\hline & Japan & 0.56 & 0.43 & 0.28 & 0.44 & 0.48 & 0.57 & 1.12 & 1.46 & 1.79 & 1.91 \\
\hline & South Korea & 0.54 & 0.45 & 0.41 & 0.53 & 0.58 & 0.6 & 0.87 & 1.13 & 1.16 & 1.28 \\
\hline \multirow[b]{3}{*}{ Philippines } & China & 4.02 & 4.02 & 3.67 & 3.69 & 3.45 & 3.32 & 2.7 & 3.37 & 3.02 & 2.64 \\
\hline & Japan & 12.53 & 10.67 & 9.91 & 10.11 & 10.71 & 10.23 & 9.64 & 9.19 & 10.01 & 10.55 \\
\hline & South Korea & 17.06 & 18.45 & 23.03 & 20.33 & 22.55 & 23.95 & 25.7 & 23.93 & 23.42 & 26.7 \\
\hline \multirow[b]{3}{*}{ Singapore } & China & 31.09 & 28.37 & 24.13 & 22.3 & 21.62 & 21.57 & 21.9 & 17.94 & 13.19 & 11.33 \\
\hline & Japan & 8.64 & 16.08 & 15.76 & 15.25 & 15.79 & 17.9 & 17.71 & 17.63 & 17.8 & 16.78 \\
\hline & South Korea & 13.57 & 13.11 & 15.92 & 11.11 & 10.99 & 10.75 & 11.09 & 9.69 & 10.7 & 11.5 \\
\hline \multirow{3}{*}{ Thailand } & China & 30.97 & 25.55 & 20.96 & 19.42 & 20.72 & 24.07 & 29.74 & 36.44 & 35.41 & 42.67 \\
\hline & Japan & 38.39 & 33.75 & 30.66 & 30.58 & 29.66 & 30.73 & 31.37 & 32.09 & 27.3 & 29.39 \\
\hline & South Korea & 32.84 & 30.38 & 0.83 & 25.36 & 24.5 & 26.26 & 28.75 & 26.51 & 22.26 & 27.36 \\
\hline \multirow{3}{*}{ Vietnam } & China & 15.47 & 14.01 & 14.54 & 12.57 & 16.71 & 19.37 & 15.39 & 15.08 & 14.91 & 6.36 \\
\hline & Japan & 11.4 & 11.11 & 10.84 & 11.17 & 13.19 & 13.16 & 13.47 & 12.79 & 13.98 & 14.27 \\
\hline & South Korea & 12.59 & 13.73 & 16.9 & 14.78 & 15.09 & 13.9 & 17.48 & 15.37 & 16.9 & 22.18 \\
\hline
\end{tabular}

1) Two-dimensional matrix analysis of coincidence in dimensional matrix of outbound preference and country China, Japan and South Korea's outbound preferences for ASEAN countries: This paper takes the outbound preference index as the ordinate and the country consistency as the abscissa. The two intersect with each other to form a twoconsistency, which provides an in-depth analysis of the differences among China, Japan and South Korea's outbound tourism to ASEAN countries.

TABLE III. MATRIX OF CHINA, JAPAN AND SOUTH KOREA's PREFERENCE FOR ASEAN AND CONSISTENCY

\begin{tabular}{|c|c|c|c|c|c|}
\hline \multirow{2}{*}{$\begin{array}{l}\text { Compare } \\
\text { items }\end{array}$} & \multicolumn{5}{|l|}{ Consistency } \\
\hline & & China and Japan & China and South Korea & Japan and South Korea & China, Japan and South Korea \\
\hline \multirow[t]{7}{*}{ Preference } & \multirow{2}{*}{$\begin{array}{l}\text { High } \\
(20 \%-40 \%)\end{array}$} & & & & \multirow{2}{*}{ Thailand, Singapore } \\
\hline & & & & & \\
\hline & \multirow{2}{*}{$\begin{array}{l}\text { Relatively high } \\
(10 \%-20 \%)\end{array}$} & & & \multirow{2}{*}{ Philippines } & \\
\hline & & & & & \\
\hline & \multirow{2}{*}{$\begin{array}{l}\text { Relatively low } \\
(10 \%-5 \%)\end{array}$} & & & \multirow{3}{*}{ Malaysia, Vietnam } & \\
\hline & & & & & \\
\hline & Low (below 5\%) & Cambodia & Brunei, Indonesia & & Laos, Myanmar \\
\hline
\end{tabular}


It's found in study that among countries for which China and Japan, China and South Korea had the same preference, the outbound preference was less than $5 \%$, among countries for which Japan and South Korea had the same preference lowest, the preferences were distributed in relatively low and relatively high preferences. Among countries for which the three countries had the same preference, the outbound preferences polarized. China and Japan, China and South Korea had the same preference for countries with low outbound preference, which was related to the economic development level and political background of the two countries. China is a developing country and Japan is a developed country, and the two countries are at different economic levels and have different needs for tourism. In addition, China and Japan have different political backgrounds, so they have the same preference for countries relatively backward in tourism. Japan and South Korea are developed countries, with small economic disparity, and similar population size, country size, and political pattern, so they have the same preference for countries with high outbound preference.

\section{Analysis of Competitiveness in Tourism Service Trade}

1) Analysis of market share index of tourism service trade export: Export market share index is the proportion of a country's total export volume to the world's total exports, reflecting the overall competitiveness or competitive position of a country's exports. The ratio of the total export volume of a country's total export volume to the world's total export volume of similar industries can reflect the international competitiveness or competitive position of a country's industry. This paper uses the ratio of ASEAN countries' export volume of tourism service trade to ASEAN's total trade in tourism services to reflect the competitiveness of ASEAN countries in tourism.

TABLE IV. MARKET Share OF 10 ASEAN COUNTRIES IN TOURISM SERVICE EXPORT (\%)

\begin{tabular}{lrrrrrrrrrr}
\hline & Brunei & Cambodia & Indonesia & Laos & Malaysia & Myanmar & $\begin{array}{c}\text { The } \\
\text { Philippines }\end{array}$ & Singapore & Thailand Vietnam \\
\hline 2005 & 0.72 & 2.22 & 12.93 & 0.42 & 25.29 & 0.19 & 6.54 & 17.75 & 27.38 & 6.58 \\
2006 & 0.68 & 2.09 & 10.18 & 0.40 & 23.97 & 0.13 & 8.11 & 17.25 & 30.67 & 6.52 \\
2007 & 0.42 & 1.84 & 9.65 & 0.42 & 25.36 & 0.13 & 8.95 & 16.36 & 30.09 & 6.77 \\
2008 & 0.10 & 2.16 & 12.37 & 0.46 & 25.64 & 0.11 & 4.30 & 17.80 & 30.47 & 6.59 \\
2009 & 0.08 & 2.49 & 10.44 & 0.50 & 29.10 & 0.12 & 4.42 & 17.21 & 29.95 & 5.69 \\
2010 & 0.10 & 2.23 & 10.22 & 0.56 & 26.00 & 0.11 & 3.88 & 20.82 & 29.53 & 6.54 \\
2011 & 0.10 & 2.46 & 9.45 & 0.48 & 23.25 & 0.39 & 3.78 & 21.19 & 32.14 & 6.75 \\
2012 & 0.10 & 2.57 & 8.69 & 0.54 & 21.17 & 0.58 & 4.24 & 19.62 & 35.35 \\
2013 & 0.09 & 2.47 & 8.46 & 0.55 & 19.89 & 0.86 & 4.35 & 17.83 & 38.77 \\
2014 & 0.07 & 2.73 & 9.49 & 0.59 & 20.86 & 1.49 & 4.65 & 17.70 & 35.54 \\
2015 & 0.14 & 2.89 & 9.91 & 0.67 & 16.20 & 1.94 & 4.86 & 15.26 & 6.86 \\
2016 & 0.12 & 2.76 & 9.77 & 0.61 & 15.55 & 1.87 & 4.42 & 15.82 & 41.38 \\
\hline
\end{tabular}

According to "Table III", the export market share is divided into four levels: high market share (25\%-40\%), relatively high market share $(15 \%-25 \%)$, relatively low market share $(15 \%-5 \%)$, and low market share (5\% or less). High market share: Thailand. Thailand has always been at a high market share with slight fluctuation, but generally on the rise. Relatively high market share: Malaysia and Singapore. The market share of the two countries has shown a downward trend. Relatively low market share: Indonesia and Vietnam. Between them, Indonesia fell in a slight fluctuation, while Vietnam had a slight fluctuation but remained basically stable. Low market share: Brunei, Myanmar, Cambodia. Brunei decreased in fluctuations, Myanmar increased in fluctuations, and Laos and Cambodia remained basically stable.

2) Trade competitive advantage index: Trade competitiveness index refers to the proportion of the difference between the import and export trade of a country in the total volume of import and export trade. The larger the coefficient, the greater the advantage is. The calculation formula of trade competitive advantage index: TC index = (export-import) / (export + import), the value range is $(-1,1)$. 
TABLE V. COMPETITIVE AdVANTAgE INDEX OF TOURISM SERVICES TRADE IN 10 ASEAN COUNTRIES

\begin{tabular}{|c|c|c|c|c|c|c|c|c|c|c|}
\hline & Brunei & Cambodia & Indonesia & Laos & Malaysia & Myanmar & The Philippines & Singapore & Thailand & Vietnam \\
\hline 2005 & -0.32 & 0.78 & 0.12 & 0.45 & 0.39 & 0.36 & -0.14 & -0.24 & 0.43 & 0.44 \\
\hline 2006 & -0.29 & 0.76 & 0.05 & 0.50 & 0.42 & 0.22 & 0.13 & -0.20 & 0.49 & 0.46 \\
\hline 2007 & -0.30 & 0.79 & 0.04 & 0.46 & 0.40 & 0.33 & 0.24 & -0.20 & 0.53 & 0.51 \\
\hline 2008 & -0.73 & 0.86 & 0.14 & 0.38 & 0.39 & 0.13 & -0.19 & -0.21 & 0.57 & 0.50 \\
\hline 2009 & -0.80 & 0.86 & 0.03 & 0.53 & 0.41 & 0.09 & -0.22 & -0.26 & 0.57 & 0.47 \\
\hline 2010 & -0.76 & 0.77 & 0.04 & 0.31 & 0.37 & 0.18 & -0.35 & -0.14 & 0.56 & 0.44 \\
\hline 2011 & -0.75 & 0.78 & 0.12 & 0.26 & 0.32 & 0.45 & -0.27 & -0.09 & 0.65 & 0.54 \\
\hline 2012 & -0.73 & 0.77 & 0.10 & 0.29 & 0.25 & 0.33 & -0.23 & -0.10 & 0.69 & 0.57 \\
\hline 2013 & -0.73 & 0.76 & 0.09 & 0.20 & 0.27 & 0.78 & -0.25 & -0.12 & 0.73 & 0.56 \\
\hline 2014 & -0.72 & 0.76 & 0.14 & 0.22 & 0.29 & 0.95 & -0.36 & -0.12 & 0.69 & 0.47 \\
\hline 2015 & -0.52 & 0.74 & 0.19 & -0.08 & 0.24 & 0.98 & -0.37 & -0.14 & 0.71 & 0.34 \\
\hline 2016 & -0.55 & 0.73 & 0.19 & 0.14 & 0.27 & 0.97 & -0.37 & -0.09 & 0.69 & 0.29 \\
\hline
\end{tabular}

The TC index is calculated based on the import and export volume of each country's tourism service trade, and the results are shown in Table 4 . TC between $(-1,-0.6)$ indicates great competitive disadvantage, $(-0.6,-0.3)$ indicates relatively great competitive disadvantage, $(-0.3,0)$ indicates weak competitive disadvantage, $(0,0.3)$ indicates weak competitive advantage, $(0.3,0.6)$ indicates relatively great competitive advantage, and $(0.6,1)$ indicates great competitive advantage. According to the TC Index, Brunei, Singapore, and the Philippines all had competitive disadvantage, among which the competitive disadvantage of Brunei was increasing. Singapore and the Philippines had weak competitive disadvantage, and had not changed much over the years. TC in Indonesia, Myanmar, Laos, Malaysia, Thailand, Vietnam and Cambodia were all positive and indicated competitive advantage in trade. Indonesia, Myanmar, and Laos had weak competitive advantages, among which Indonesia had basically remained unchanged, Myanmar's advantages continued to increase, and Laos was falling in advantage. Malaysia, Thailand, and Vietnam had relatively great competitive advantage, among which Malaysia's advantage was continuously weakening,
Thailand's was increasing, and Cambodia's was stable in fluctuation, averaging above 0.7 .

3) Revealed comparative advantage index: The revealed comparative advantage index [12-14] is a comparative advantage reflecting the trade of an industry in a certain country (region). It removes the influence of the fluctuations of the total amount of the country and the world, and better reflects the relative advantages of the industry. The formula is: $R C A=\left(X_{i j} / Y_{i}\right) /\left(X_{w j} / Y_{W}\right)$, where $X_{i j}$ represents the export value of commodity $\mathrm{j}$ from country i, ${ }^{i}$ represents the total export value of country i's products, and $Y_{W}$ represents the total export value of the world's products. According to the standard proposed by Japan External Trade Organization (JERTO), RCA greater than 2.5 indicates strong international competitiveness; RCA between 2.5-1.25 indicates relatively strong international competitiveness; RCA between 1.25-0.8 indicates moderate international competitiveness; RCA < 0.8 indicate weak international competitiveness.

TABLE VI. REVEALED COMPARATIVE AdVANTAGE INDEXES OF 10 ASEAN COUNTRIES

\begin{tabular}{|c|c|c|c|c|c|c|c|c|c|c|}
\hline & Brunei & Cambodia & Indonesia & Laos & Malaysia & Myanmar & $\begin{array}{c}\text { The } \\
\text { Philippines }\end{array}$ & Singapore & Thailand & Vietnam \\
\hline 2005 & 0.76 & 4.02 & 1.00 & 8.29 & 1.21 & 0.44 & 1.00 & 0.49 & 1.61 & 1.53 \\
\hline 2006 & 0.70 & 0.03 & 0.01 & 0.04 & 0.01 & 0.00 & 0.01 & 0.00 & 0.01 & 0.01 \\
\hline 2007 & 0.51 & 3.55 & 0.79 & 6.16 & 1.27 & 0.21 & 1.44 & 0.45 & 1.69 & 1.27 \\
\hline 2008 & 0.11 & 4.14 & 0.96 & 4.40 & 1.33 & 0.18 & 0.81 & 0.48 & 1.71 & 1.12 \\
\hline 2009 & 0.11 & 3.61 & 0.80 & 3.01 & 1.55 & 0.17 & 0.83 & 0.48 & 1.62 & 0.90 \\
\hline 2010 & 0.14 & 4.81 & 0.74 & 2.93 & 1.41 & 0.18 & 0.71 & 0.58 & 1.64 & 1.04 \\
\hline 2011 & 0.11 & 4.69 & 0.63 & 2.93 & 1.30 & 0.72 & 0.85 & 0.59 & 1.82 & 0.96 \\
\hline 2012 & 0.11 & 5.03 & 0.66 & 3.91 & 1.29 & 1.00 & 0.96 & 0.59 & 1.65 & 0.76 \\
\hline 2013 & 0.12 & 3.84 & 0.65 & 2.32 & 1.16 & 1.06 & 0.89 & 0.50 & 2.13 & 0.74 \\
\hline 2014 & 0.11 & 4.17 & 0.77 & 2.87 & 1.22 & 1.70 & 0.86 & 0.50 & 2.03 & 0.70 \\
\hline 2015 & 0.29 & 3.44 & 0.86 & 2.59 & 1.03 & 1.87 & 0.82 & 0.45 & 2.23 & 0.58 \\
\hline 2016 & 0.34 & 2.81 & 0.86 & 2.23 & 1.02 & 1.81 & 0.75 & 0.48 & 2.21 & 0.56 \\
\hline
\end{tabular}

According to "Table V", it can be seen that RCA indexes of the ten countries in 2006 were less than 0.8 , which was the lowest in all countries in history except Brunei. In the following analysis, the analysis of 2016 all countries is excluded except Brunei. RCA indexes of Cambodia and Laos were greater than 2.5, which had strong competitive but showed a downward trend. Thailand's RCA index was greater than 1.25 and its advantages continued to expand, and it had relatively strong competitiveness. Indonesia, Myanmar, the Philippines, Vietnam, and Malaysia had moderate competitiveness, among which Indonesia and the Philippines were in a downward trend, Myanmar was rising fast, and Malaysia was stable. The competitiveness of Brunei and Singapore was relatively weak, between which the 
competitiveness of Brunei continued to decline, and Singapore was stable.

\section{CONCLUSION}

- From the perspective of tourist flow, in terms of the outbound tourist flow of the three countries, the countries with high tourist flow and low tourist flow were basically the same, and the difference was mainly concentrated in the moderate tourist flow. The reasons for this difference are as follows: In terms of geographical location, China, Japan and South Korea are adjacent to ASEAN, but the distances of sea and land are significantly different, so China tends to prefer Vietnam, while Japan and South Korea tend to prefer the Philippines. In terms of economic level, Japan and South Korea are developed countries, and China is a developing country. Japan and South Korea's economies developed earlier and their initial outbound tourist flow was relatively stable, while China's outbound tourism developed late due to the effect of economic development, and its outbound tourist flow fluctuated greatly. In terms of political environment, Indonesia's Chinese exclusion has a huge impact on the outbound tourist flow of China and South Korea, and Huangyan Island incident has a great impact on China and the Philippines. In terms of population, after 2007, the outbound tourist flow to ASEAN increased significantly with the improvement of the domestic economy, which was directly related to the large population base of China. Compared with Japan and South Korea, outbound tourism in China is at an initial stage.

- From the perspective of tourism preference, the countries for which every two countries among China, Japan and South Korea have the same preference are concentrated, mainly with low preference. The countries for the three countries have the same preference are polarized.

- From the perspective of tourism competition, Singapore's export market share is high but its trade competition advantage index and revealed comparative advantage index are both low, indicating that Singapore's tourism development has slowed down. Brunei's three indexes are all low, and its tourism has been at a low level of development. The market share of Cambodia and Myanmar is low, but their trade competitiveness index and revealed comparative advantage index are both high, indicating that the two countries are on the rise of tourism.

Overall, China, Japan and South Korea's tourism preferences for the ten ASEAN countries are positively related to their tourism competitiveness. Thailand's outbound preference and competitiveness have always been relatively high. Singapore's tourism industry developed earlier, but its performance has been sluggish in recent years, its competitiveness has declined, and its outbound preference is also declining. Tourism in Cambodia, Myanmar, and Laos started late and the starting point was low, but the tourism industry in these countries continued to heat up, while China, Japan and South Korea's outbound tourism preferences for these three countries also fluctuate.

\section{REFERENCES}

[1] Auliana Poon. Tourism, Technology and Competitive Strategy, CABI Publishing, CAB International, 1997, pp. 123-126; Written by Francois Vera, translated by Luo Jiezhen, International Tourism Economy and Policy, Tourism Education Press, 1989, pp.12; Paulo Rita "Tourism in the European Union", InternationalJournal of Contemporary Hospitality Management, 2000 (12), pp. 434-436. 参 见 Auliana Poon.Tourism, Technology and Competitive Strategy, CABI Publishing, CAB International, 1997, pp. $123-126$; 弗朗 索瓦・韦拉著, 罗结珍译《国际旅游经济与政策》, 旅游教育出 版社,1989 年, 12 页; Paulo R ita“Tourism in the European Union" , International Journal of Contemporary Hospitality Management, 2000 (12), pp. $434-436$.

[2] Ma Yong, Zhou Juan. Asia-Pacific Tourism Market Analysis and Marketing Strategy Innovation [J]. World Geography, 2003 (04): 9095. 马勇,周娟.亚太旅游市场分析与营销战略创新 [J].世界地理, 2003(04):90-95.

[3] Zhang Meng, Evaluation of Regional Tourism Competitiveness: Index Construction and Method Selection [J]. Tourism Journal, 2007, (02): $13 \sim 17$. 张梦, 区域旅游业竞争力评价:指标构建与方法选择 [J]. 旅游学刊, 2007, (02):13 17.

[4] Douglas G.Pearce."Competitive Destination Analysis in Southeast Asia", Journal of Travel Research,Spring,1997,12(4), pp.37-41.

[5] Zou Chunmeng: Analysis of Regional Tourism Integration Strategies in ASEANand Effects, Asia-pacific Economic Review, 2007 (2). 邹 春萌: 《东盟区域旅游一体化策略与效应分析》, 《亚太经济》 2007 年第 2 期。

[6] Su Kewu, Li Mingxing. Comparison of International Competitiveness of China and ASEAN's Tourism Service Trade - Based on Analysis of Panel Data: 1990-2006 [J]. Journal of Henan Normal University (Philosophy and Social Science), 2008,35 (J). 06): 74-78. 苏科五,李 明星.中国与东盟旅游服务贸易国际竞争力比较——基于面板数 据的分析： 1990 2006[J].河南师范大学学报(哲学社会科学 版),2008,35(06):74-78.

[7] Vannaith Chheang. "Tourism and Regional Integration in Southeast Asia” 2013-05,http://www.ide.go.jp/English/Publish/Books/index.html

[8] Ye Li, Chen Xiuqian. Interaction Analysis of Tourism Trade of China and ASEAN Countries Based on Evaluation of Tourism Competitiveness[J]. Economic Geography, 2013, 33(12): 177-181. 叶 莉,陈修谦.基于旅游竞争力评价的中国与东盟国家旅游贸易互动 分析 [J].经济地理,2013,33(12):177-181.

[9] Hu Aiqing. Analysis of Regional Tourism Competitiveness in ASEAN [J]. Southeast Asian Studies,2014(05):35-44. 胡爱清.东盟区 域旅游竞争力分析[J].东南亚研究,2014(05):35-44.

[10] Sun Gennian, Zhou Lu. Study on the Relationship between Japan, South Korea and 8 ASEAN countries' Inbound Tourism to China and Import \& Export Trade [J]. Human Geography, 2012, 27(06):87-94. 孙根年,周露.日韩东盟 8 国入境我国旅游与进出口贸易关系的研 究[J].人文地理,2012,27(06):87-94.

[11] Chen Qiao, Cheng Cheng, SongJianlin.Study on the Interactive Relationship between Tourism and Trade between China and ASEAN[J].Guangxi Social Sciences,2017(10):72-77. 陈乔,程成,宋建 林. 中国一东盟旅游与贸易互动关系研究 [J].广西社会科 学,2017(10):72-77.

[12] Bela.Balassa.Trade Liberalisation and'Revealed'Comparative Advantage[J].The Manchester School,1965(33):99-123.

[13] Balassa Bela.The Changing Pattern of Comparative Advantage in Manufactured Goods[J].The Review of Economics and Statistics, 1979(May).259-266. 
[14] Balassa Bela.Comparative Advantage in Manufactured Goods:A Reappraisal[J].The Review of Economics and Statistics, 1986(May). 315-319. 